\title{
Extraosseous odontoma in the mouth floor: report of a case and literature review
}

\author{
Cédric Seckinger ${ }^{1}$, Stéphane Wang², Daniel Anastasio ${ }^{3}$ \\ Praticien hospitalier, U.F de Thionville, Service d'Odontologie CHR Metz-Thionville, France \\ Praticien hospitalier, U.F de Metz, Service d'Odontologie CHR Metz-Thionville, France \\ Praticien hospitalier, Chef de Service U.F de Thionville, Service d'Odontologie CHR Metz-Thionville, France \\ Correspondence: seckinger@hotmail.fr
}

(Received 22 October 2014, accepted 29 August 2015)

Key words:

peripheral odontoma / extraosseous odontoma / odontogenic tumor

Mots clés :

odontome périphérique / odontome extraosseux / tumeur odontogénique

\begin{abstract}
Introduction: 0dontoma growing in the extraosseous soft tissue is very rare. Only seven cases of peripheral odontoma have been published to date. Observation: A case of peripheral odontoma arising in the mouth floor of a 10 year-old girl is reported. $0 n$ the basis of the clinical appearance and localization, the first suggested diagnosis was lipoma. After surgical excision, the diagnosis of peripheral odontoma was proposed and confirmed by scanning electron microscopy. Discussion: Extraosseous odontoma are rarely observed. The suspected mechanism is that remnants of odontogenic epithelium entrapped in the oral soft tissues may be a potent source for peripheral odontogenic tumor differentiation. Conclusion: This case of peripheral odontoma occurring in the mouth floor is the first reported in the literature, to our knowledge. Possible explanations regarding its origin lie in embryological assumptions.
\end{abstract}

Résumé - Odontome peripherique au niveau du plancher buccal : cas clinique et revue de literature. Introduction : Les odontomes périphériques extraosseux de la cavité buccale sont extrêmement rares. Seuls sept cas ont été rapportés à ce jour dans la littérature. Observation : Le cas d'une localisation d'un odontome périphérique au niveau du plancher buccal chez une jeune fille de 10 ans est rapporté. Sur la base de son aspect clinique et compte tenu de sa localisation, le premier diagnostic proposé était celui d'un lipome. Après exérèse chirurgicale, le diagnostic d'odontome périphérique est avancé. Il était confirmé par un examen au microscope électronique à balayage. Discussion : Les odontomes extraosseux sont rarement observés. Les explications acceptées sont que des restes de l'épithélium odontogéniques seraient piégés au sein des tissus mous oraux et pourraient être une origine possible de tumeur odontogène périphérique. Conclusion : Ce cas clinique d'odontome périphérique extraosseux du plancher buccal est à notre connaissance le premier publié dans cette localisation. Son origine s'expliquerait par une hypothèse embryologique.

\section{Introduction}

Odontomas are defined as hamartomas of odontogenic origin. They are composed of all the structures forming dental tissue. Two types are well-defined: complex odontomas and compound odontomas [1]. The compound type is made up of the tooth-like structures that are radiographically opaque. Complex odontomas are defined as a mixture of odontogenic tissues without dental organization.

Odontomas have been found almost exclusively in the jaws but other localizations have been reported, such as the auricula media [2,3], the cheek [4], and the naso-pharynx [5]. The medical literature first described intraosseous odontomas, second extraosseous odontomas or soft tissue odontomas, and third peripheral odontomas (POs). POs are defined as tumors with the histological characteristics of intraosseous odontomas but developing only in the soft tissue covering the teeth-bearing parts of the mandible and the maxillae. Only seven cases of peripheral odontomas have been published to date [6-11].

\section{Observation}

A ten-year-old female was referred to the department of oral surgery with a hard mass located in the left paramedian area of her mouth floor (Fig. 1). Oral examination revealed a firm yellow mass under the superficial mucosa. The child complained only of slight discomfort in lingual protraction.

Given the clinical appearance of the lesion and its localization, the preoperative diagnosis was lipoma induratumor or 


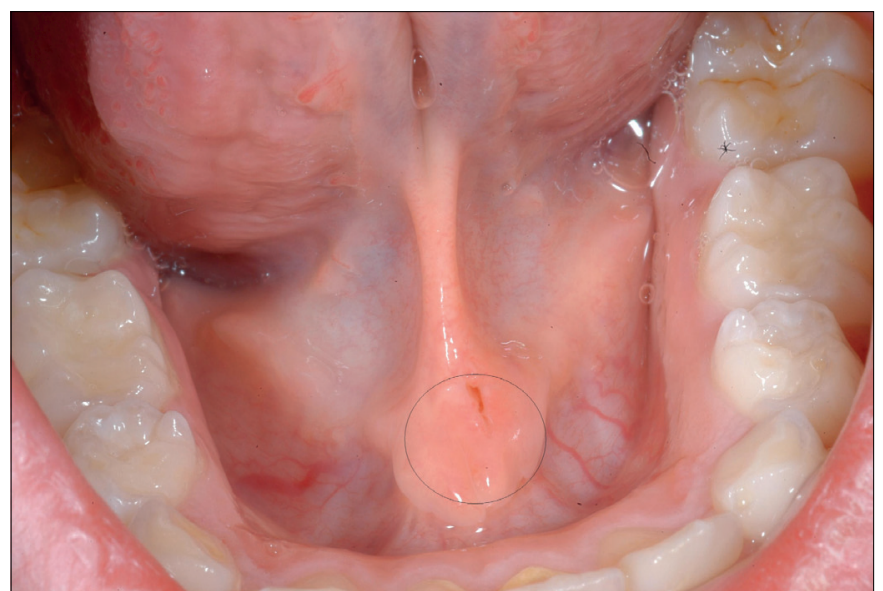

Fig. 1. Odontoma localization on the oral cavity floor.

Fig. 1. Localisation de l'odontome au niveau du plancher buccal.

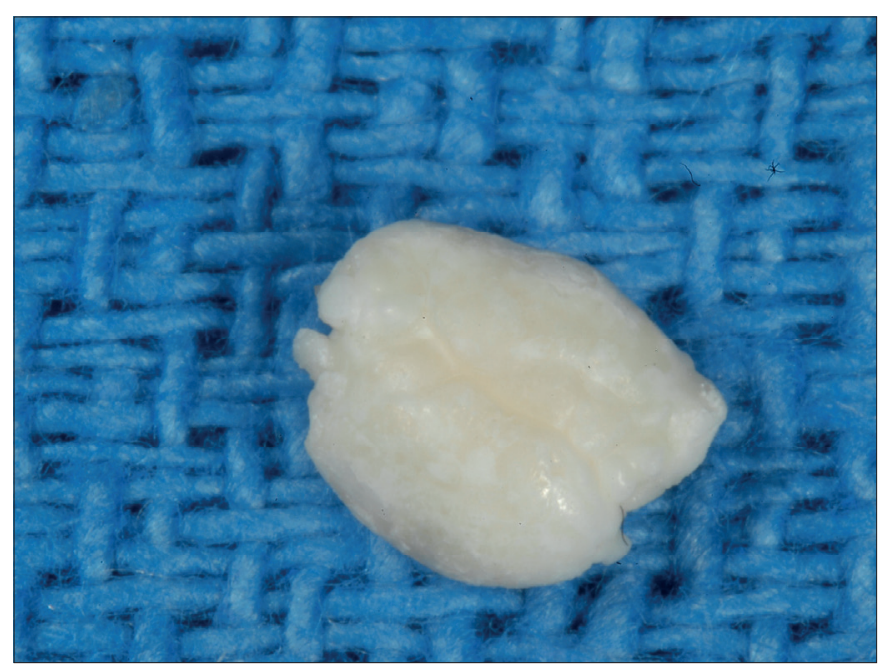

Fig. 2. Peripheral odontoma presenting as an ovoid, glossy mass. Fig. 2. Odontome périphérique se présentant comme une masse brillante ovoïde.

salivary calculus. Irrespective of the diagnosis, the only appropriate treatment was excision.

Surgical removal under local anesthesia was planned 8 days later. An incision on the lesion's top surface revealed an ovoid, smooth, well-delimited, glossy mass (Fig. 2). The lesion was dissected and excised without any difficulty. The macroscopic appearance and scanning electron microscopy led to diagnosis of a peripheral extraosseous complex odontoma (Figs. 3, 4). The patient was free of symptoms after the operation and no complications were recorded.

\section{Review of the seven peripheral odontoma cases previously reported in the medical literature}

1. Swan [6] described the first case in a 19-year-old Black patient presenting a firm multinodular mass of $1.5 \mathrm{~cm}$ in

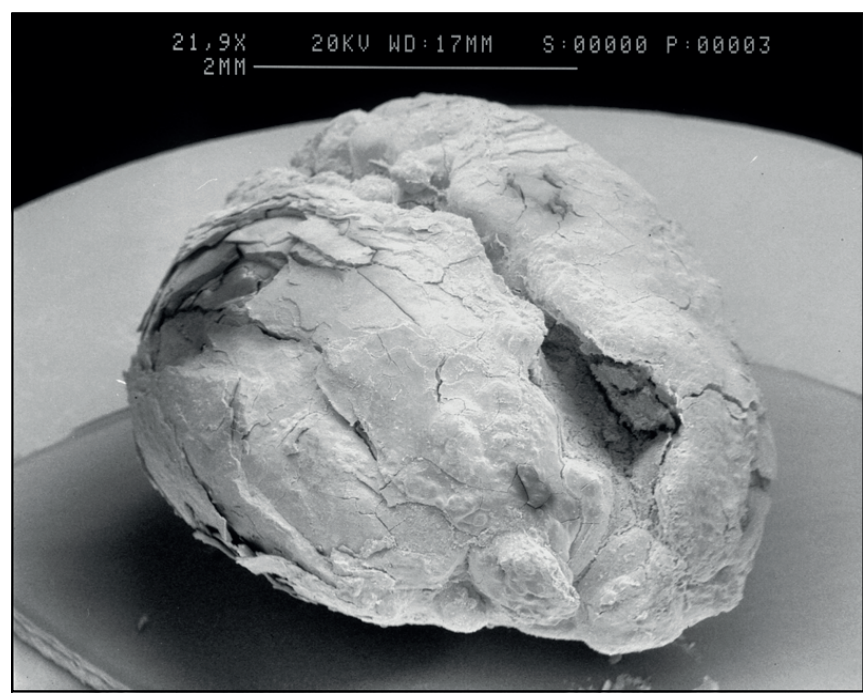

Fig. 3. Odontoma analysis (SEM).

Fig. 3. Analyse de l'odontome (MEB).

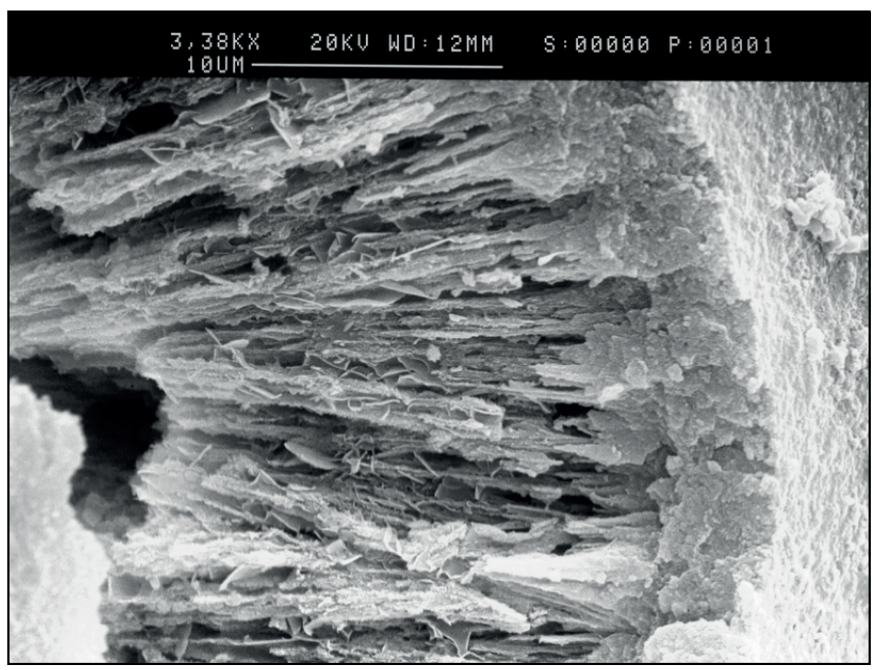

Fig. 4. Dentine heart and beaches of irregular enamel without pulp tissue (SEM).

Fig. 4. Cœur de dentine et plages irrégulières d'émail sans tissu pulpaire (MEB).

diameter in the submucosal vestibular oral area located between the left maxillary canine tooth. Radiographically, multiple small tooth-like structures were seen inside the tumor between the anatomical crown and the interproximal bone. The final microscopic diagnosis was compound odontoma.

2. Giunta and Kaplan [7] described two cases. Case 1: A 5-year-old female Caucasian presented a pink, slightly emergent, non-tender, $2.5 \mathrm{~mm}$ in diameter lesion in palatal localization, facing the left maxillary second deciduous molar. The removed tumor was a firm tooth-like tissue mass of 2.0 to $3.0 \mathrm{~mm}$ in diameter. The lesion was diagnosed as 


\section{A S C L I N I Q U E}

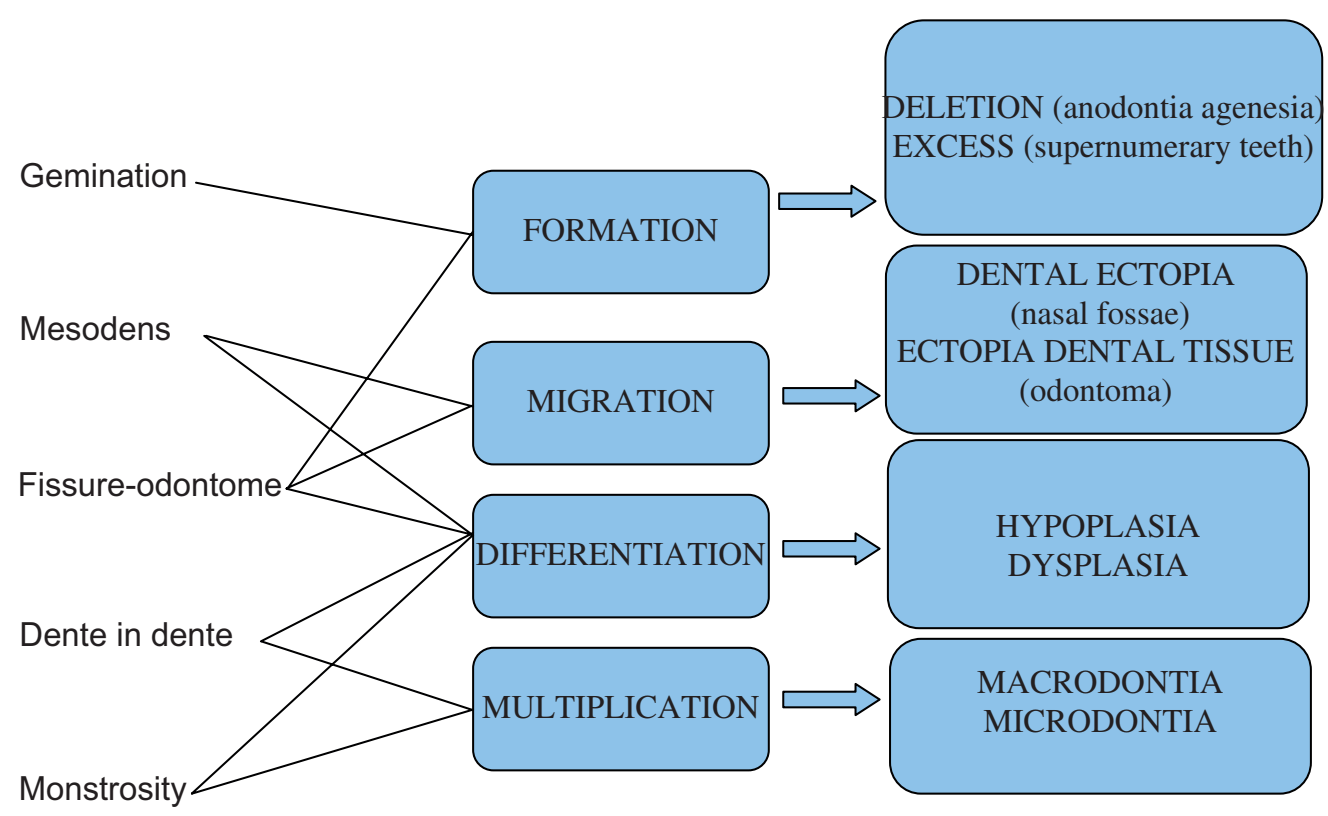

Fig. 5. Neurocristopathic classification of the dental anomalies according to Couly [14].

Fig. 5. Classification neurocristopathique des anomalies dentaires selon Couly [14].

a peripheral compound odontoma on the basis of the histological findings and the clinical data. Case 2: A 21-year-old male Caucasian presented an opaque mass, $6 \mathrm{~mm}$ in diameter in the inter-dental gum lying between the first and the second right mandibular molars. Histopathologic and clinical data enabled the diagnosis of peripheral compound odontoma.

3. Ide et al. [8] reported a case where a 39-year-old male presented a small, asymptomatic, limited, and firm mass measuring $10 \times 8 \times 6 \mathrm{~mm}$. It was located in the gum between the lateral incisor and canine of the left maxilla. On the basis of the clinical and histopathological findings, the tumor was diagnosed as a peripheral complex odontoma.

4. Castro et al. [9] reported a 6-year-old Black male patient presenting a dome-shaped gingival mass under the lingual fibromucosa membrane facing the left mandibular second deciduous molar. The lesion was pink, firm, non-tender and measured $2.5 \mathrm{~mm} \times 1.5 \mathrm{~cm}$. The removed gingival mass was ovoid and hard, measuring $1.0 \mathrm{~cm} \times 1.0 \mathrm{~cm} \times 0.25 \mathrm{~cm}$. The microscopic diagnosis stated was a compound peripheral odontoma.

5. Ledesma-Montes et al. [10] described a 3-year-old Mexican child presenting an asymptomatic tumor measuring $10 \times$ $12 \mathrm{~mm}$, in the lingual gum located between the lower left deciduous canine and first molar. Clinical and histological diagnosis considered it was a compound peripheral odontoma.

6. Junquera et al. [11] published a case in a 23-year-old man presenting with a firm gingival mass on the left posterior maxilla that had gradually enlarged over one year. The mass was reported as complex odontoma.
Two other publications concerning peripheral odontoma developing in newborns and overlying the mucosa of the palate can be added [12-13].

\section{Discussion}

It is during the third week of embryogenesis in the course of neurulation and stemming from the ectoblast, that tissues which will contribute to form the cephalic pole develop. At the stage of neurula, the ectoderm of the maxillary and mandibular buds, as well as the one covering the brachial arches and the tongue, are in the shape of well-demarcated strips spreading over the edge of the neural plate.

Six branchial arches exist but only five are developed at this stage. At the level of the primary branchial arch, Meckel's cartilage and its derivatives, the mandible, the malleus, the incus, the malar, the salivary glands, the auricle and the auditory meatus, are formed. Appear also at this site, the trigeminal nerve, the mylo-hyoid muscle, the anterior bulge of the musculus digastricus, the exterior pharyngo-staphyloid muscle, the tympanic membrane, and the Eustachian tube.

The right and left maxillary buds are part of the first branchial arch and are covered by the ectoderm contributing to the formation of the mouth floor.

The mouth floor acquires individual characteristics at the time of the several lingual and mandibular buds forming in the mesobranchial field. The embryogenesis of the dental system is indissociable from cephalic embryogenesis because teeth originate from neurulation [14] (Fig. 5). 
Lumsden [15] showed that the mammalian odontoblast is a cell deriving from the cephalic neural crest and that the ectoderm of the first arch appears to be the initial embryological determining factor in the genesis both of the crown shape and the positioning of each tooth (epiblastic dental placode). Indeed, the buccal ectoderm is organized into epiblastic dental placodes specific for each individual tooth, with each placode constituting the quality component as the ectoderm fixes in the site and the positioning of each tooth as well as the shape of the crown.

These extraosseous remnants of odontogenic epithelium could be considered as a potent source to differentiate into dental germ after induction [13]. The term peripheral odontoma, by definition, excludes any tumorous development within bony tissues or in an erupted tooth.

However, the PO remains histologically and morphologically identical to the extraosseous odontoma. Out of the seven presented cases of P0, four appeared on the maxillae (two in the maxilla gum and two in the palatal mucosa), and three were located on the mandible in the lingua gum. Most of these cases were discovered in a young population (1st or 2 nd decade of life).

The major interest of our report lies in the discovery of an extraosseous odontoma in the floor of the mouth, which could be the only case recorded in the scientific literature. This atypical localization may be explained by the numerous interconnections between the different anatomical components during embryology.

\section{Conclusions}

To our knowledge, this case of odontoma occurring in the mouth floor is currently the only one described in the medical literature. Possible explanations regarding its origin lie in embryological theories with the basic understanding of cell migrations.

Despite the scarcity of odontoma reports, surgical intervention and histological analysis are both required to confirm the non-malignant nature.

Conflicts of interests: none declared

\section{Références}

1. Kramer IRH, Pindborg JJ, Shear M. The WHO Histological Typing of Odontogenic Tumours. A commentary on the Second Edition. Cancer. 1992;70(12):2988-94.

2. Bellucci RJ, Zizmor J, Goodwin RE. Odontoma of the middle ear: a case presentation. Arch otolaryngol. 1975;101:571-3.

3. Prasad S, Hirsch B, Kamerer DB, Curtin H. Odontoma of the middle ear cleft. Am J Otol. 1991;12:452-5.

4. El Sedfy Bakry N. An ectopic odontome in the cheek. Oral Surg Oral Med Oral Pathol, 1977; 43:583-4.

5. McClure G. Odontoma of the naso-pharynx. Arch otolaryngol. 1946;44:51-60.

6. Swan R. Odontoma. A review, case presentation and periodontal considerations in treatment. J Periodontol. 1987;58:856-60.

7. Giunta JL, Kaplan MA. Peripheral, soft tissue odontomas. Two case reports. Oral Surg Oral Med Oral Pathol. 1990;69:406-11.

8. Ide F, Shimoyama T, Horie N. Gingival peripheral odontoma in an adult: case report. J Periodontol. 2000;71:830-2.

9. Castro GW, Houston G, Weyrauch C. Peripheral odontoma: report of case and review of literature. J Dent Child. 1994;61:209-13.

10. Ledesma-Montes C, Perez-Bache A, Garcés-Ortiz M. Gingival compound odontoma. Int J Oral Maxillofac Surg. 1996;25:296-7.

11. Junquera L, De Vicente JC, Roig P, Olay S, Rodriguez-Recio 0 . Intraosseus odontoma erupted into the oral cavity: an unusual pathology. Med Oral Patol Oral Cir Bucal. 2005;10:248-51.

12. Mikami T, Yagi M, Mizuki H, Takeda Y. Congenital peripheral developing odontoma accompanied by congenital teratomatous fibroma in a 9 month-old boy: a case report. $\mathrm{J}$ Oral Sci. 2013;55:89-91.

13. Silva AR, Carlos-Bregni R, Vargas PA, de Almeida OP, Lopes MA. Peripheral developing odontoma in newborn. Report of two cases and literature review. Med Oral Patol Oral Cir Bucal. 2009;14(11):612-5.

14. Couly G. Développement céphalique : Embryologie, croissance, pathologie. Ed. Cdp. Paris. 1991.

15. Lumsden AG. Spatial organization of the epithelium and the role of neural crest cells in the initiation of the mammalian tooth germ. Development. 1988;103 Suppl.:155-69. 